\title{
Training Path Selection for Innovative Talents of College Physical Education
}

\author{
Zongxian $\mathrm{Yu}$ \\ Aba Teachers College, Aba 623004, China
}

Keywords: College; Physical education; Innovative talents

\begin{abstract}
To train innovative talents for higher education is one of important tasks of college education and also the need of socialist construction with Chinese characteristics. College physical education plays an important role in training innovative talents. Accurately cognizing the important role of innovative talents is very necessary for further training innovative talents for college physical education. This paper discusses the positive function of college physical education for training innovative talents and proposes main paths to train innovative talents for college physical education.
\end{abstract}

\section{Introduction}

Innovative talents refer to the talents with creative spirit, innovative thinking and innovation ability. As China's higher education reform continuously goes deep, how should colleges as important bases of training creative talents cultivate high-quality innovative talents? This has become a significant topic. Nowadays, physical education reform of Chinese colleges is constantly deepening. However, intensity of reform is not sufficient. In particular, the potential of innovative talent training fails to be stimulated. To better discover potential of physical education, it is required to carefully study innovative talent training paths for college physical education.

\section{Positive role of college physical education in training innovative talents}

Firstly, college physical education can train good physical quality and psychological quality of innovative talents. College physical education can apply a unique way to give play to a positive role for physical and psychological health of college students. College students can improve their physique, temper individual will and develop individualities through physical exercise. Through learning physical exercise theories, college students can practically form favorable physical exercise habits. This will contribute to opening their mind in more harmonious and fair physical education environment, and continuously increasing the opportunity for contacting and communicating with others so as to eliminate guarding mentality. Physical activities have such traits of justice, joy and competition. They are not just very beneficial to keeping healthy, but also can give vent to heavy psychological burden so that college students can gain self-affirmation or others' praise. Physical activities can not just help students establish positive outlook on life, but also eliminate various bad emotions. Particularly, collective physical activities can enlighten social consciousness of college students, intensify their sense of responsibility and consciousness and cultivate their good teamwork spirit. The above factors own huge irreplaceable effects on training innovative talents. Secondly, college physical education can train favorable aesthetic consciousness of innovative talents. As an important content of cultivating aesthetics ability of college students, physical education is a kind of exercise practice. This is a distinct characteristic of physical education different from other types of education. People are not just the subjects of physical exercise, but also the main aesthetic objects. Healthy physique, shape and muscle show beauty of human health. The strength, speed and agility shown in physical exercise reveal human natural beauty. In physical exercise process, people may organically combine internal beauty and external beauty, improve practical feeling of beauty, deepen comprehension of beauty and stimulate unremitting pursuit of beauty. It thus can be seen that physical education owns very rich aesthetics implication and has good functions on training aesthetic consciousness of innovative talents. 


\section{Main paths to train innovative talents for college physical education}

\section{Help college students establish innovation consciousness through improving educational methods}

To innovate educational method, it is required to introduce interactivity of physical education and apply discussion-based teaching, heuristic teaching and practical teaching to train divergent thinking of college students and the ability to discover problems, analyze problems and solve problems. Besides, it is required to change passive learning to active learning, digest and link accumulated knowledge to achieve innovation of techniques and skills. Teachers should also give students the space of independent thinking, promote college students' awareness of participating in physical education learning and innovation spirit through equal communication between teacher and students so as to realize the effect of half efforts and double results in learning theoretical courses of physical education. Due to comprehensiveness and diversity of teaching mode, it is very beneficial to help students' innovation consciousness.

\section{Develop college students' creative thinking ability through forming subject consciousness}

To train creative thinking ability of college students, it is required to motivate curiosity of college students and train their independent personality. The essence of creative thinking ability is to seek innovation and change. In college physical education, favorable atmosphere where college students can freely express independent opinions and discuss actively and relaxing and harmonious learning environment should form. This will be very beneficial to training creative thinking ability of college students majoring in physical education. College physical education teachers should overall realize college students are the real masters of physical education, guide them to conduct inquiry learning and group cooperative learning more actively in teaching process so as to let college students really understand and master connotation of physical education. It is required to transform original traditional teaching to creation of favorable learning environment based on college students' experience so that college students can really grow to sports fans. Teachers should become guides and partners in learning process. Teachers and students should mutually exchange their thought and emotions, share their knowledge and opinions, and learn anytime and anywhere according to teaching course and students' actual learning conditions. College students should be encouraged to form more creative learning modes. In this way, their learning potential can be better mobilized. It thus can be seen that in college physical education, physical education teachers shall enlighten students' innovative thinking as far as possible, give them time and space form free training, make them give play to creative thinking and gain ideal effects. Therefore, this fully proves the important function of college students' subject consciousness in creative thinking ability.

Boost innovative personality development though excavating personal potential of college students

Innovation is not just the ability development process, but also a process in need of elaborate training. In other words, in order to improve innovation ability of a college student, it is required to train and innovate relevant personality characteristics. In college physical education, college students must become masters in classroom and establish subjectivity status of college students in order to better mobilize subjective initiative of college students majoring in physical education and their thinking activities and make then discover, analyze and solve problems after observation and thinking. Only when we practically stimulate interest and internal motivation of physical education talents can their creative thinking ability be fully mobilized. Meanwhile, the potential of innovative talents of physical education can be better excavated. In college physical education, teachers must pay attention to developing students' personal potential, boost fitness consciousness of physical education talents and cultivate their innovative personality. Since physical quality of college students majoring in physical education, personality development must be intensified. Multiple teaching methods shall be applied for experience and trail so as to practically find out contents and methods which can adapt personal features of physical education talents. Nowadays, most college students are only child in their families. Their weak points mainly concentrate on individual mind and volitional quality. But, their physical quality is not deficient. Thus, based on strengthening their physical quality, 
psychological traits and volitional quality of college students should improve. Of course, physical education teachers also need to positively guide and encourage physical education students to respect and help each other, form harmonious and friendly good style and cultivate their independent personality. Compared with other courses, creative teaching of physical education owns an irreplaceable role in developing independent personality.

\section{Guarantee realization of innovative education objective through innovating physical education management system}

Of course, a large number of colleges leg behind in terms of physical education course setting and badly need reform. However, limited by sports ground, equipment and professional teachers, college students have to choose courses according to the specified item and number. Thus, many students cannot choose their desired physical education courses. Hence, it is required to deeply study how to improve teaching conditions to meet course selection requirements of college students. This is a problem college education management system reform should mainly solve. It is required to start from good health of college students and comprehensively analyze physical education course performance of college students. Previously, the judgment of college physical education course performance was dominated by the results of sport event. Although theory course and ordinary performance were involved, the proportion was quite small. This performance evaluation mode cannot meet the needs of health physical education and lifelong physical education, let lone meet the needs of colleges to train innovative talents. Meanwhile, in the process of improving management system of college physical education teachers, the current situation where physical education teachers only contact with teaching and research office and the office of teaching affairs should be changed. The opportunities of direct communication between college students and physical education teachers should continuously increase. At present, a large number of colleges arrange physical education teachers to serve as physical education instructors. However, since various schools and departments have no right to directly lead and manage physical education teachers, physical education teachers purely fulfill their obligation in spare-time tutorship. Thus, it is hard to improve their subjective initiative. Hence, it is required to innovate current physical education management mechanism, input special funds to employ physical education teachers to serve as physical education instructors so as to ensure standardized management of extracurricular physical education tutorship.

Improve innovation quality of physical education workers through multi-aspect efforts

Firstly, pioneering spirit of physical education teachers should be motivated. College should walk out of conformism and complacent state. Physical education is always conducted dynamically. Physical exercise not just owns complexity, but also has variety and diversity. Hence, in college physical education, even if the same teaching material is adopted, teachers should adopt different teaching methods for diverse students. Teachers should be good at letting college students gain the joys of physical education innovation and carefully listen to their aspirations. Thus, teachers must carefully learn, continuously accept further education and boost their innovation quality. Secondly, new knowledge and new skills of physical education teachers shall improve actively. Except teaching, knowledge and ability of physical education teachers will generate significant effects on innovation ability of college students. College education reform aims to help teachers to continue to boost professional knowledge and ability. This requires teachers combining theoretical knowledge and practical experience in a more scientific and creative way to improve experience to a higher level and enrich teaching contents. This will be very beneficial to cultivating innovative talents of physical education. Thirdly, it is required to enhance to training innovation enthusiasm and will of physical education teachers. To make sure innovation consciousness of physical education teachers can last long, larger input and unremitting will are required. Only when teachers are full of enthusiasm can they input more emotion in it; only when teachers own strong will can they be fearless of danger and difficulty. Therefore, it is required to enhance cultivation of teachers' input in innovation ability and strong will and penetrate these in the whole process of college education in order to gain actual effects. 


\section{Conclusions}

In general, implementation of innovation physical education which aims to train innovation spirit and innovation ability of college students promotes and deepens modern physical education idea. But, as a modern physical education view, creative education is not machine-made for effects on education. College physical education workers should combine educational practice, comprehensive take into account of education conditions and objects, reposition education functions and practically adjust physical education contents and teaching methods so as to establish training mode of innovation physical education talents and bring new hope for college physical education.

\section{Acknowledgments}

Fund program: Study on hand key culture features and inheritance (ASB14-02); Study on physical training service based on Aba Teachers' College (ASB14-10).

\section{References}

[1] Xue Wenzhong, Chen Ru, Li Dunjie, College physical education reform should pay attention to innovation. Journal of Guangzhou Physical Education Institute, 2003 (23).

[2] Wei Ping, Training physical education innovation ability of common college students. Journal of Physical Education, 2004 (4).

[3] Zheng Quehui, Cope with innovative talent training and perfect college curriculum system. China Higher Education, 2008 (10).

[4] Shi Lifeng, Li Chengxiao, Thought on reform and development of college physical education. Journal of Chengdu Sport University, 2009 (1).

[5] Li Pinghe, Han Changjiu, Thought of constructing inquiry learning course based on physical education. Research on New Courses, 2009 (2). 